\title{
Preparation and characterization of magnetic
} nanoparticles containing $\mathrm{Fe}_{3} \mathrm{O}_{4}$-dextrananti- $\beta$-human chorionic gonadotropin, a new generation choriocarcinoma-specific gene vector

\author{
This article was published in the following Dove Press journal: \\ International Journal of Nanomedicine \\ I February 201। \\ Number of times this article has been viewed
}

\author{
Cai Jingting ${ }^{1,2}$ \\ Liu Huining' \\ Zhang Yi' \\ 'Department of Obstetrics and \\ Gynecology, Xiangya Hospital, \\ Central South University, Changsha, \\ Hunan, People's Republic of China; \\ ${ }^{2}$ Department of Gynecological \\ Oncology, Hunan Tumor Hospital, \\ Changsha, Hunan, People's Republic \\ of China
}

Objective: To evaluate the feasibility of using magnetic iron oxide $\left(\mathrm{Fe}_{3} \mathrm{O}_{4}\right)$-dextran-anti- $\beta$-human chorionic gonadotropin (HCG) nanoparticles as a gene vector for cellular transfections.

Study design: $\mathrm{Fe}_{3} \mathrm{O}_{4}$-dextran-anti- $\beta$-HCG nanoparticles were synthesized by chemical coprecipitation. The configuration, diameter, and iron content of the nanoparticles were detected by transmission electron microscopy (TEM), light scatter, and atomic absorption spectrophotometry. A3-(4,5)-dimethylthiahiazo(-z-y1)-3,5-di-phenytetrazoliumromide assay was used to evaluate the cytotoxicity of $\mathrm{Fe}_{3} \mathrm{O}_{4}$-dextran-anti- $\beta$-HCG nanoparticles. Enzyme-linked immunosorbent assay and indirect immunofluorescence were used to evaluate immunoreactivity. The efficiency of absorbing DNA and resisting deoxyribonuclease I (DNase I) digestion when bound to $\mathrm{Fe}_{3} \mathrm{O}_{4}-$ dextran-anti- $\beta$-HCG nanoparticles was examined by agarose gel electrophoresis. The ability of $\mathrm{Fe}_{3} \mathrm{O}_{4}$-dextran-anti- $\beta$-HCG nanoparticles to absorb heparanase antisense oligodeoxynucleotides (AS-ODN) nanoparticles in different cell lines was evaluated by flow cytometry. The tissue distribution of heparanase AS-ODN magnetic nanoparticles in choriocarcinoma tumors transplanted in nude mice was detected by atomic absorption spectrophotometry.

Results: TEM demonstrated that the shape of nanoparticles is irregular. Light scatter revealed nanoparticles with a mean diameter of $75.5 \mathrm{~nm}$ and an iron content of $37.5 \mu \mathrm{g} / \mathrm{mL}$. No cytotoxicity was observed when the concentration of $\mathrm{Fe}_{3} \mathrm{O}_{4}$-dextran-anti- $\beta$-HCG nanoparticles was $<37.5 \mu \mathrm{g} / \mathrm{mL}$. $\mathrm{Fe}_{3} \mathrm{O}_{4}$-dextran nanoparticles have a satisfactory potential to combine with $\beta$-HCG antibody. Agarose gel electrophoresis analysis of binding experiments showed that after treatment with sodium periodate, $\mathrm{Fe}_{3} \mathrm{O}_{4}$-dextran-anti- $\beta$ - $\mathrm{HCG}$ nanoparticles have a satisfactory potential to absorb DNA, and the protection experiment showed that nanoparticles can effectively protect DNA from DNase I digestion. Aldehyde $\mathrm{Fe}_{3} \mathrm{O}_{4}$-dextran-anti- $\beta$-HCG nanoparticles can transfect reporter genes, and the transfection efficiency of these nanoparticles is greater than that of liposomes $(P<0.05)$. $\mathrm{Fe}_{3} \mathrm{O}_{4}$-dextran-anti- $\beta$-HCG nanoparticles can concentrate in choriocarcinoma cells and in transplanted choriocarcinoma tumors.

Conclusions: The results confirm that $\mathrm{Fe}_{3} \mathrm{O}_{4}$-dextran-anti- $\beta$-HCG nanoparticles have potential as a secure, effective, and choriocarcinoma-specific targeting gene vector.

Keywords: magnetic nanoparticles, $\mathrm{Fe}_{3} \mathrm{O}_{4}$-dextran-anti- $\beta$-HCG, choriocarcinoma, targeting vector, gene vector

Gene therapy modifies gene expression for therapeutic gain. Over the last two decades, gene therapy research has moved from preclinical to clinical studies for many diseases, ranging from single-gene disorders, such as cystic fibrosis and Duchene muscular dystrophy, to multigenic diseases, such as cancer. ${ }^{1}$ 
In most gene therapy studies, a 'corrected' therapeutic gene is inserted into the genome to replace an 'abnormal' disease-causing gene. A vector (ie, a carrier) must be used to deliver the therapeutic gene to the patient's target cells. The most common vectors are viruses, but viral vectors are often toxic or immunogenic and make it difficult to verify successful infection of the targeted cells.

An ideal gene delivery system should be stable, biocompatible, nontoxic, cost-effective, and capable of transferring exogenous, highly anionic genetic materials (ie, DNA, antisense oligodeoxynucleotides [AS-ODNs], short interfering ribonucleic acids [RNAs]) into tissue-specific sites. A primary goal of gene therapy is to target vectors and the genes of interest efficiently to specific cell types. Recent advances in nanoparticle technology have yielded new types of gene vectors.

Magnetic iron oxide $\left(\mathrm{Fe}_{3} \mathrm{O}_{4}\right)$ nanoparticles are considered ideal gene vectors because they are simple to manufacture, have diameters of $<10 \mathrm{~nm}$, are able to absorb a significant amounts of DNA, demonstrate limited cellular toxicity, and can be guided to specific sites via magnets. In addition, to improve biocompatibility, iron oxide nanoparticles can be embedded in various macromolecules, such as polysaccharides and proteins. However, human organs such as liver, spleen, and lymph (among others) are infused with a reticuloendothelial system and have the ability to passively absorb nanoparticles through phagocytosis. Because $\beta$-human chorionic gonadotropin (HCG) is expressed only in choriocarcinomas, anti- $\beta$-HCG monoclonal antibody were attached to magnetic particles to allow the nanoparticles to target the tissues of interest.

In this study, nanometer-sized dextran-coated iron oxide particles modified with an anti- $\beta$-HCG monoclonal antibody were synthesized, and the feasibility of using $\mathrm{Fe}_{3} \mathrm{O}_{4}{ }^{-}$ dextran-anti- $\beta-H C G$ as a gene vector was tested.

\section{Material and methods Materials}

All reagents used for nanoparticle synthesis were commercial products. Dextran (40,000 MW; T-40), deoxyribonuclease I (DNase I), and bovine serum albumin (BSA) were purchased from Sigma-Aldrich Corporation (St. Louis, MO). Lipofectamine ${ }^{\mathrm{TM}} 2000$ was purchased from Invitrogen Corporation (Carlsbad, CA). Mouse anti-human $\beta$-HCG monoclonal antibody was purchased from Wolwo Biotechnology (Shanghai, China). Goat anti-mouse immunoglobulin G/fluorescein isothiocynate (IgG/FITC) and goat antimouse IgG/horseradish peroxidase (HRP) were purchased from Shiruike Biotechnology (Shanghai, China). DNA marker ФX174-Hinc II digest was obtained from TaKaRa Corporation (Shiga, Japan). Analytical grade chemicals (ie, $\mathrm{FeCl}_{3} \cdot 6 \mathrm{H}_{2} \mathrm{O}$, and $\mathrm{FeCl}_{2} \cdot 4 \mathrm{H}_{2} \mathrm{O}$ ) were obtained from local suppliers. All aqueous solutions were prepared using distilled water and filtered through $0.22-\mathrm{mm}$ membranes.

JEG-3 and JAR human choriocarcinoma cell lines were purchased from American Type Culture Collection (ATCC, Manassas, VA). RL95-2, Hela, HepG2, and Lovo cell lines were supplied by the cell center of Central South University (Changsha, China).

Female BALB/c nude mice (4 weeks old) were supplied and fed by the animal division of Central South University.

Glyceraldehyde-3-phosphate dehydrogenase (GAPDH) AS-ODN was synthesized by Shanghai Sangon Biological Engineering Technology and Services Company Ltd (Shanghai, China). The GAPDH AS-ODN sequence was 5'-GAC CTT CAC CAT CTT GTC TA-3', with a 5' terminal FITC group including some phosphorothioated nucleotides. Oligonucleotides were diluted to $100 \mu \mathrm{mol} / \mathrm{L}$ and stored at $-20^{\circ} \mathrm{C}$.

\section{Cell culture studies}

JEG-3, JAR, RL95-2, Hela, HepG2, and Lovo cell lines were cultured in Roswell Park Memorial Institute (RPMI) medium (Invitrogen) supplemented with 10\% fetal calf serum.

\section{Preparation and physical characterization of magnetic $\mathrm{Fe}_{3} \mathrm{O}_{4}-$ dextran-anti- $\beta$-HCG nanoparticles Preparation of nanoparticles}

$\mathrm{Fe}_{3} \mathrm{O}_{4}$-dextran-anti- $\beta$-HCG nanoparticles were prepared as described by Xia et al. ${ }^{2}$ Dextran $(5 \mathrm{~g}), \mathrm{FeCl}_{3} \cdot 6 \mathrm{H}_{2} \mathrm{O}(0.552 \mathrm{~g})$, and $\mathrm{FeCl}_{2} \cdot 4 \mathrm{H}_{2} \mathrm{O}(0.45 \mathrm{~g})$ were dispersed in $10 \mathrm{~mL}$ water. The mixture was titrated to alkaline by $10 \mathrm{~mL}$ of $5 \mathrm{~mol} / \mathrm{L}$ ammonia and quickly heated to $60^{\circ} \mathrm{C}$, with magnetic stirring. After $30 \mathrm{~min}$, the suspension was neutralized with acetic acid. Aggregates were removed by centrifugation for $10 \mathrm{~min}$. The dextran-coated iron oxide nanoparticles were separated from unbound dextran by magnetic separator and eluted with $10 \mathrm{~mL}$ sodium acetate $(\mathrm{pH}$ 6.5). The dextran-coated iron oxide suspension was oxidized with sodium periodate $\left(\mathrm{NaIO}_{4}\right)$ with magnetic stirring in the dark at $4^{\circ} \mathrm{C}$ for $1 \mathrm{~h}$ to drive aldehyde termination. The solution was dialyzed while under magnetic stirring. Then, $100 \mu \mathrm{g}$ mouse anti-human $\beta$-HCG monoclonal antibody was mixed with $1 \mathrm{~mL}$ aldehyde dextran-coated iron oxide nanoparticle solution. The solution was kept in the dark at $4^{\circ} \mathrm{C}$ for $24 \mathrm{~h}$ 
and then blocked by $50 \mu \mathrm{L} 10 \% \mathrm{wt} / \mathrm{vol} \mathrm{BSA}$. To improve stability, $1 \mathrm{~mol} / \mathrm{L}$ sodium borohydride $\left(\mathrm{NaBH}_{4}\right)$ was added to the compound at $4{ }^{\circ} \mathrm{C}$ for $3 \mathrm{~h}$ and stirred. Finally, the suspension was centrifuged for $20 \mathrm{~min}$ at 13,000 rpm, repeated three times. The final product was dispersed in $1 \mathrm{~mL}$ sodium perborate $\left(\mathrm{NaBO}_{3}\right)\left(\mathrm{pH} \mathrm{8.5)}\right.$ and preserved at $4{ }^{\circ} \mathrm{C}$.

\section{Morphological determination}

The $\mathrm{Fe}_{3} \mathrm{O}_{4}$-dextran-anti- $\beta$-HCG nanoparticles solution was titrated with a copper wire. After drying, morphological structure was determined by CM120 transmission electron microscopy (TEM) (Philips, Eindhoven, The Netherlands).

\section{Effective diameter determination}

$\mathrm{Fe}_{3} \mathrm{O}_{4}$-dextran-anti- $\beta$-HCG nanoparticles were dispersed in high-purity water using ultrasound vibration and placed into a color matching cup. The effective diameter was determined using a Mastersizer 2000 Laser Particle Size Analyzer (Malvern Instruments, Malvern, UK).

\section{Evaluation of iron content}

Iron content was determined by atomic absorption Spectra-30 Photometer (Varian Instruments, Palo Alto, CA).

\section{Effect of $\mathrm{Fe}_{3} \mathrm{O}_{4}$-dextran-anti- $\beta$-HCG nanoparticles on cells$$
\text { Toxicity of } \mathrm{Fe}_{3} \mathrm{O}_{4} \text {-dextran-anti- } \beta \text {-HCG }
$$ nanoparticle}

JEG-3 cells were seeded in 96-well plates (5000 cells/ well) in media containing various concentrations of $\mathrm{Fe}_{3} \mathrm{O}_{4}$ dextran-anti- $\beta$-HCG nanoparticles $(0,18.75,30.0,37.5$, 56.25 , and $75 \mu \mathrm{g} / \mathrm{mL}$ ). After $24 \mathrm{~h}$, MTT (Sigma) was added and incubated for $4 \mathrm{~h}$. Cells were washed with phosphatebuffered saline (PBS) and stained with purple formazan solubilized in $100 \%$ dimethyl sulfoxide. Absorbance was read at $570 \mathrm{~nm}$. The inhibitory rate of $\mathrm{Fe}_{3} \mathrm{O}_{4}$-dextran-anti- $\beta$-HCG nanoparticles was calculated as $\left(\mathrm{OD}_{570}\right.$ control group - $\mathrm{OD}_{570}$ experimental group/ $\mathrm{OD}_{570}$ control group).

\section{Immunological features of $\mathrm{Fe}_{3} \mathrm{O}_{4}^{-}$ dextran-anti- $\beta$-HCG nanoparticles} Enzyme-linked immunosorbent assays for $\mathrm{Fe}_{3} \mathrm{O}_{4}$-dextran-anti- $\beta$-HCG nanoparticles

JEG-3 cells were seeded in 96-well plates (5000 cells/well). Aldehyde $\mathrm{Fe}_{3} \mathrm{O}_{4}$-dextran-anti- $\beta$-HCG nanoparticle, nonaldehyde $\mathrm{Fe}_{3} \mathrm{O}_{4}$-dextran-anti- $\beta$-HCG nanoparticle (anti- $\beta$-HCG monoclonal antibody was mixed with nonoxidized dextran-coated iron oxide nanoparticles), and anti- $\beta-\mathrm{HCG}$ monoclonal antibody solutions (at 10, 50, 80100 , or $150 \mu \mathrm{g} / \mathrm{mL}$ anti- $\beta$-HCG monoclonal antibody) were titrated into the wells ( $100 \mu \mathrm{L} /$ well) which were incubated for $1 \mathrm{~h}$ at $37^{\circ} \mathrm{C}$. Dextrancoated iron oxide nanoparticles served as a control. After washing two times, goat antimouse IgG/HRP (diluted 1:2000) was added into each well and wells were incubated at $37^{\circ} \mathrm{C}$ for $1 \mathrm{~h}$. Solutions were prepared by addition of $3,3^{\prime}, 5,5^{\prime}$ tetramethylbenzidine peroxidase, for $15-20 \mathrm{~min}$ at $37^{\circ} \mathrm{C}$, and the reactions were stopped by addition of $2 \mathrm{M} \mathrm{H}_{2} \mathrm{SO}_{4}(50 \mu \mathrm{L} /$ well). Optical density (OD) was read at $492 \mathrm{~nm}$ immediately after stopping the reaction in an ELX808 Ultra Microplate Reader (Bio-Tek, Winooski, VT). All samples were prepared in triplicate. The percent transfection was calculated as OD anti- $\beta$-HCG monoclonal antibody activity of aldehyde or nonaldehyde $\mathrm{Fe}_{3} \mathrm{O}_{4}$-dextran-anti- $\beta$-HCG nanoparticle/OD anti- $\beta-H C G$ monoclonal antibody $\times 100$.

\section{Indirect immunofluorescence assay for $\mathrm{Fe}_{3} \mathrm{O}_{4}$-dextran-anti- $\beta$-HCG nanoparticles}

JEG-3 cells were seeded onto slides and incubated in culture dishes for $48 \mathrm{~h}$. The cells were then incubated with aldehyde $\mathrm{Fe}_{3} \mathrm{O}_{4}$-dextran-anti- $\beta$-HCG nanoparticle solution, nonaldehyde $\mathrm{Fe}_{3} \mathrm{O}_{4}$-dextran-anti- $\beta$-HCG nanoparticle solution, and anti- $\beta$-HCG monoclonal antibody solution which contained $100 \mu \mathrm{g} / \mathrm{mL}$ anti- $\beta$-HCG monoclonal antibody at $4^{\circ} \mathrm{C}$ for $30 \mathrm{~min}$. JEG-3 cells were then cultured for another 30 min, fixed using paraformaldehyde, treated with trinitrotoluene, and incubated with goat antimouse IgG/FITC at $37^{\circ} \mathrm{C}$ for $30 \mathrm{~min}$. Slides were sealed with glycerin, and images were observed at 400 by fluorescence microscopy (Axiolab; Carl Zeiss Shanghai Co Ltd, Guangzhou, China).

\section{Evaluation of $\mathrm{Fe}_{3} \mathrm{O}_{4}$-dextran-anti- $\beta$-HCG nanoparticles as gene vectors Preparation of $\mathrm{Fe}_{3} \mathrm{O}_{4}$-dextran-anti- $\beta$-HCG-GAPDH AS-ODN mixtures}

Mouse antihuman $\beta$-HCG monoclonal antibody $(10 \mu \mathrm{g})$ and GAPDH AS-ODN $(20 \mu \mathrm{L}$ in $100 \mu \mathrm{mol} / \mathrm{L})$ were mixed with $100 \mu \mathrm{L}$ aldehyde or nonaldehyde dextran-coated iron oxide nanoparticles. Following incubation in the dark at $4^{\circ} \mathrm{C}$ for $24 \mathrm{~h}$, the mixture was blocked by $5 \mu \mathrm{L}$ of $10 \% \mathrm{wt} / \mathrm{vol}$ bovine serum albumin (BSA). To improve stability, $1-\mathrm{mol} / \mathrm{L} \mathrm{NaBH}_{4}$ was added to the mixture at $4^{\circ} \mathrm{C}$ and stirred for $3 \mathrm{~h}$. Finally, the suspension was centrifuged for $20 \mathrm{~min}$ at $13,000 \mathrm{rpm}$, the supernatant removed, and dispersed again with $100 \mu \mathrm{L} \mathrm{NaBO}_{3}(\mathrm{pH} \mathrm{8.5)}$. This centrifugation and wash step were repeated three times. 


\section{Electrophoretic assessment of nanoparticle complexes}

Aldehyde $\mathrm{Fe}_{3} \mathrm{O}_{4}$-dextran-anti- $\beta$-HCG-GAPDH AS-ODN, nonaldehyde $\mathrm{Fe}_{3} \mathrm{O}_{4}$-dextran-anti- $\beta$-HCG-GAPDH AS-ODN, and GAPDH AS-ODN $(20 \mu \mathrm{mol} / \mathrm{L})$ were separated by gel electrophoresis and visualized by ethidium bromide staining. Samples were analyzed using GeneScan Analysis software and GeneScan Genotyper software (Applied Biosystems, Foster City, CA). Aldehyde $\mathrm{Fe}_{3} \mathrm{O}_{4}$-dextran-anti- $\beta$-HCG nanoparticle solution served as a control.

\section{$\mathrm{Fe}_{3} \mathrm{O}_{4}$-dextran-anti- $\beta$-HCG nanoparticles protect DNA from DNase I}

Aldehyde $\mathrm{Fe}_{3} \mathrm{O}_{4}$-dextran-anti- $\beta$-HCG-GAPDH AS-ODN, nonaldehyde $\mathrm{Fe}_{3} \mathrm{O}_{4}$-dextran-anti- $\beta$-HCG-GAPDH AS-ODN, and GAPDH AS-ODN $(20 \mu \mathrm{mol} / \mathrm{L})$ were subjected to DNase I at $37^{\circ} \mathrm{C}$ for $1 \mathrm{~h}$. Products were identified by gel electrophoresis and visualized by ethidium bromide staining. Results were obtained by GeneScan Analysis software and GeneScan Genotyper software (Applied Biosystems).

\section{Efficiency of $\mathrm{Fe}_{3} \mathrm{O}_{4}$-dextran-anti- $\beta$-HCG nanoparticles as gene vector}

JEG-3 cells were seeded in six-well plates in culture media containing $\mathrm{Fe}_{3} \mathrm{O}_{4}$-dextran-anti- $\beta$-HCG-GAPDH AS-ODN/ FITC compounds $\left(20-\mu \mathrm{mol} / \mathrm{L}\right.$ AS-ODN, $\left.37.5-\mu \mathrm{g} / \mathrm{mL} \mathrm{Fe}^{3+}\right)$, $\mathrm{Fe}_{3} \mathrm{O}_{4}$-dextran-anti- $\beta$-HCG nanoparticles $\left(37.5-\mu \mathrm{g} / \mathrm{mL} \mathrm{Fe}^{3+}\right)$, GAPDH AS-ODN/FITC (20- $\mu \mathrm{mol} / \mathrm{L}$ AS-ODN), and liposome-GAPDH AS-ODN/FITC compounds $(20-\mu \mathrm{mol} / \mathrm{L}$ AS-ODN). Pure culture media served as controls. Following transfection, cells were cultured for $24 \mathrm{~h}$, digested with trypsin $(0.25 \%)$, and washed three times with PBS (centrifuged for $5 \mathrm{~min}$ at $1000 \mathrm{rpm}$ to remove free fluorescence). Fluorescence intensity $\left(10^{6}\right.$ cells) was measured by flow cytometry.

\section{Absorption of $\mathrm{Fe}_{3} \mathrm{O}_{4}$-dextran-anti- $\beta$-HCG- GAPDH AS-ODN in different cell type}

JEG-3, JAR, RL95-2, Hela, HepG2, and Lovo cells were seeded in six-well plates and transfected with $\mathrm{Fe}_{3} \mathrm{O}_{4}-$ dextran-anti- $\beta$-HCG-GAPDH AS-ODN/FITC compounds $\left(20-\mu \mathrm{mol} / \mathrm{L}\right.$ AS-ODN, $\left.37.5-\mu \mathrm{g} / \mathrm{mL} \mathrm{Fe}^{3+}\right)$. Fluorescence intensity was measured using flow cytometry as described.

\section{Distribution of $\mathrm{Fe}_{3} \mathrm{O}_{4}$-dextran-anti- $\beta$-HCG nanoparticles in nude mice}

Cultured JEG-3 cells were harvested and resuspended in naive RPMI medium at $4-6 \times 10^{6}$ cells $/ \mathrm{mL}$, and $100 \mu \mathrm{L}$ were immediately injected into the flank of eight nude mice. When tumor diameter reached $\sim 8-10 \mathrm{~mm}, \mathrm{Fe}_{3} \mathrm{O}_{4^{-}}$ dextran-anti- $\beta$-HCG nanoparticle solution $(0.5 \mathrm{~mL} / \mathrm{mouse}$, $1.5 \mathrm{mg} / \mathrm{mL} \mathrm{Fe}^{3+}$ ) was injected into tail veins of eight mice; the hypodermal tumor of four mice (group I) were treated with a 12,000 gauss, 1-cm-diameter magnetic stick, and four mice (group II) were not treated. Dextran-coated iron oxide nanoparticle solution $\left(0.5 \mathrm{~mL} /\right.$ mouse, $\left.1.5 \mathrm{mg} / \mathrm{mL} \mathrm{Fe}^{3+}\right)$ was also injected to four mice (group III) through the tail vein. After $30 \mathrm{~min}, 100 \mathrm{mg}$ of tissue was harvested from heart, liver, spleen, lung, kidney, and choriocarcinoma hypodermal tumors of all mice and digested (nitric acid:perchloric acid, 4:1). Iron content was measured by atomic absorption using a Spectra-30 Photometer.

\section{Statistical analysis}

Statistical significance was assessed using Student's $t$-test or analysis of variance (ANOVA) (one-way ANOVA followed by Dunnett's test) using SAS (SAS Institute, Cary, NC). Differences between means were considered significant at $P<0.05$.

\section{Results}

Morphology and diameter of $\mathrm{Fe}_{3} \mathrm{O}_{4}$-dextran-anti- $\beta$-HCG nanoparticles $\mathrm{Fe}_{3} \mathrm{O}_{4}$-dextran-anti- $\beta$-HCG nanoparticle solution is atramentous and transparent. Using TEM, nanoparticles of uniform size and irregular shape (Figure 1) were observed. The average diameter was $75.5 \mathrm{~nm}($ range $=33.7-84.7 \mathrm{~nm})$.

The iron content of $\mathrm{Fe}_{3} \mathrm{O}_{4}$-dextran-anti- $\beta$-HCG nanoparticles is $37.5 \mu \mathrm{g} / \mathrm{mL}$.

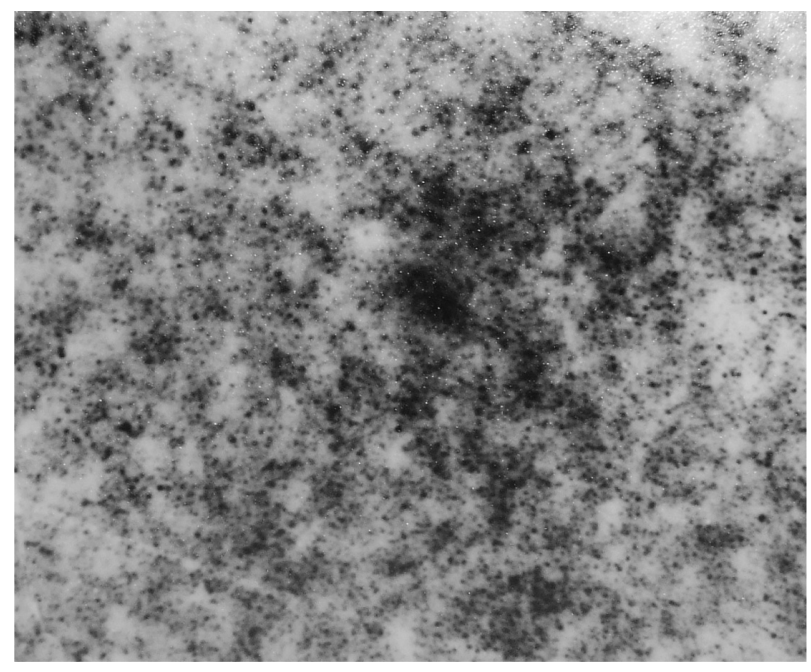

Figure I Transmission electron micrograph of magnetic iron oxide $\left(\mathrm{Fe}_{3} \mathrm{O}_{4}\right)$ dextran-anti- $\beta$-HCG nanoparticles.

Abbreviations: HCG, human chorionic gonadotropin. 


\section{Toxicity of $\mathrm{Fe}_{3} \mathrm{O}_{4}$-dextran-anti- $\beta$-HCG nanoparticles}

As shown in Table 1, the inhibitory rate of nanoparticles at 56.25 and $75 \mu \mathrm{g} / \mathrm{mL}$ is higher than control $(P<0.05)$. In contrast, a significant difference was not observed between nanoparticle concentrations at $18.75,30$, or $37.5 \mu \mathrm{g} / \mathrm{mL}$ and control $(P>0.05)$.

\section{Enzyme-linked immunosorbent assay for $\mathrm{Fe}_{3} \mathrm{O}_{4}$-dextran-anti- $\beta$-HCG nanoparticles}

The transfection efficiency of anti- $\beta-H C G$ monoclonal antibody activity in aldehyde $\mathrm{Fe}_{3} \mathrm{O}_{4}$-dextran-anti- $\beta$ - $\mathrm{HCG}$ nanoparticle is $>85 \%$, whereas the transfection rate of anti- $\beta$-HCG monoclonal antibody activity in nonaldehyde $\mathrm{Fe}_{3} \mathrm{O}_{4}$-dextran-anti- $\beta$-HCG nanoparticle is $\sim 13 \%(P<0.05)$ (Table 2).

\section{Indirect immunofluorescence assay for $\mathrm{Fe}_{3} \mathrm{O}_{4}$-dextran-anti- $\beta$-HCG nanoparticles} Upon treatment with aldehyde $\mathrm{Fe}_{3} \mathrm{O}_{4}$-dextran-anti- $\beta$-HCG/ FITC nanoparticle solution, JEG-3 cells surrounded by fluorescent (Figure 2A) were noted. A similar result was obtained with anti- $\beta-H C G$ antibody (Figure $2 \mathrm{~B}$ ). Together, these data suggest that $\mathrm{Fe}_{3} \mathrm{O}_{4}$-dextran-anti- $\beta$-HCG nanoparticles bind with JEG-3 cells in a manner similar to anti- $\beta$-HCG antibody. Nonaldehyde $\mathrm{Fe}_{3} \mathrm{O}_{4}$-dextran-anti- $\beta$-HCG/FITC nanoparticles cannot combine with JEG-3 cells because there are no fluorescent substances on JEG-3 cells (Figure 2C).

\section{$\mathrm{Fe}_{3} \mathrm{O}_{4}$-dextran-anti- $\beta$-HCG}

\section{nanoparticles as a gene vector}

DNA in nonaldehyde $\mathrm{Fe}_{3} \mathrm{O}_{4}$-dextran-anti- $\beta$-HCG-GAPDH AS-ODN complexes migrate in agarose gels (Figure 3, third track), similar to migration of simple GAPDH AS-ODN (second track). This indicates that nonaldehyde $\mathrm{Fe}_{3} \mathrm{O}_{4}$-dextran nanoparticles cannot combine with GAPDH AS-ODN. After oxidization with $\mathrm{NaIO}_{4}$, aldehyde $\mathrm{Fe}_{3} \mathrm{O}_{4}-$ dextran nanoparticles are able to combine with GAPDH AS-ODN, so the DNA in aldehyde $\mathrm{Fe}_{3} \mathrm{O}_{4}$-dextran-anti$\beta$-HCG-GAPDHAS-ODN complexes is retained in the loading well (Figure 3, fourth track). On the other hand, there is no DNA in $\mathrm{Fe}_{3} \mathrm{O}_{4}$-dextran-anti- $\beta$-HCG nanoparticles, hence the compounds migrate either in the fifth track or in the loading well.

\section{$\mathrm{Fe}_{3} \mathrm{O}_{4}$-dextran-anti- $\beta$-HCG nanoparticles protect DNA from DNase I}

The absence of a DNA band in second and third tracks indicates that the DNA in nonaldehyde $\mathrm{Fe}_{3} \mathrm{O}_{4}$-dextran-anti$\beta$-HCG-GAPDH AS-ODN complexes and simple GAPDH AS-ODN is digested by DNase I. In contrast, DNA in the aldehyde $\mathrm{Fe}_{3} \mathrm{O}_{4}$-dextran-anti- $\beta$-HCG-GAPDH AS-ODN complexes is retained in the loading well of fourth track, indicating that $\mathrm{Fe}_{3} \mathrm{O}_{4}$-dextran-anti- $\beta$-HCG nanoparticles protect DNA from DNase I digestion (Figure 4).

\section{Efficiency of $\mathrm{Fe}_{3} \mathrm{O}_{4}$-dextran-anti- $\beta$-HCG nanoparticle as gene vector}

The fluorescence intensity of group IV in JEG-3 cells is higher than that of groups I, II, III, and V $(P<0.05)$ (Table 3$)$, indicating that $\mathrm{Fe}_{3} \mathrm{O}_{4}$-dextran-anti- $\beta$-HCG nanoparticles are effective as a gene vector. Interestingly, the efficiency of gene transfection using $\mathrm{Fe}_{3} \mathrm{O}_{4}$-dextran-anti- $\beta$-HCG nanoparticles is higher than that observed using liposomes $(P<0.05)$.

\section{Absorption of $\mathrm{Fe}_{3} \mathrm{O}_{4}$-dextran-anti- $\beta$ - HCG-GAPDH AS-ODN in different cells}

The fluorescence intensity in JEG-3 and JAR cells is clearly higher than that observed in RL95-2, Hela, HepG2, and Lovo $(P<0.05)$ (Table 4$)$, while there is little difference between the fluorescence intensity of JEG-3 and JAR cells $(P>0.05)$. These results indicate that $\mathrm{Fe}_{3} \mathrm{O}_{4}$-dextrananti- $\beta$-HCG nanoparticles are more readily absorbed by choriocarcinoma cells.

\section{Distribution of $\mathrm{Fe}_{3} \mathrm{O}_{4}$-dextran-anti- $\beta$-HCG nanoparticles in nude mice}

In groups I and II, iron content in choriocarcinoma hypodermal tumors was highest in heart, liver, spleen, lung, and kidney $(P<0.05)$. At the same time, it was found that $\mathrm{Fe}^{3+}$ content in choriocarcinoma hypodermal tumors of group I was higher than that of group II $(P<0.05)$. In group III, the iron content in choriocarcinoma hypodermal tumors is less than that in liver or spleen $(P<0.05)$. These results indicate that when modified

Table I Inhibitory rate of $\mathrm{Fe}_{3} \mathrm{O}_{4}$-dextran-anti- $\beta$-HCG nanoparticle to JEG-3 cells

\begin{tabular}{lllllll}
\hline & Control group & $\mathbf{1 8 . 7 5}(\mu \mathrm{g} / \mathrm{mL})$ & $\mathbf{3 0}(\mu \mathrm{g} / \mathrm{mL})$ & $\mathbf{3 7 . 5}(\mu \mathrm{g} / \mathrm{mL})$ & $\mathbf{5 6 . 2 5}(\mu \mathrm{g} / \mathrm{mL})$ & $\mathbf{7 5}(\mu \mathrm{g} / \mathrm{mL})$ \\
\hline $\mathrm{A}_{570}$ & $0.374 \pm 0.025$ & $0.372 \pm 0.031$ & $0.368 \pm 0.027$ & $0.361 \pm 0.023$ & $0.310 \pm 0.037$ & $0.293 \pm 0.034$ \\
Inhibitory rate (\%) & 0 & 0.5 & 1.6 & 3.5 & 17.1 & 21.7 \\
\hline
\end{tabular}

Abbreviations: $\mathrm{HCG}$, human chorionic gonadotropin; $\mathrm{Fe}_{3} \mathrm{O}_{4}$, magnetic iron oxide. 
Table 2 Transfection efficiency of anti- $\beta$-HCG monoclonal antibody bound to nanoparticle

\begin{tabular}{llllll}
\hline $\begin{array}{l}\text { Antibody } \\
\text { concentration } \\
(\mu \mathrm{g} / \mathrm{mL})\end{array}$ & $\begin{array}{l}\text { Anti- } \beta \text {-HCG } \\
\text { antibody } \\
\text { (OD data) }\end{array}$ & $\begin{array}{l}\text { Aldehyde } \\
\text { nanoparticle } \\
\text { (OD data) }\end{array}$ & $\begin{array}{l}\text { Preservation } \\
\text { rate (\%) }\end{array}$ & $\begin{array}{l}\text { Nonaldehyde } \\
\text { nanoparticle } \\
\text { (OD data) }\end{array}$ & $\begin{array}{l}\text { Preservation } \\
\text { rate (\%) }\end{array}$ \\
\hline 150 & 0.441 & 0.385 & 87.3 & 0.058 & 13.2 \\
100 & 0.372 & 0.341 & 91.7 & 0.050 & 13.4 \\
80 & 0.316 & 0.282 & 89.2 & 0.041 & 13.0 \\
50 & 0.281 & 0.253 & 90.0 & 0.039 & 13.9 \\
10 & 0.227 & 0.208 & 91.6 & 0.031 & 13.7 \\
\hline
\end{tabular}

Abbreviations: HCG, human chorionic gonadotropin; OD, optical density.

by $\beta$-HCG monoclonal antibody, $\mathrm{Fe}_{3} \mathrm{O}_{4}$ nanoparticles are able to target choriocarcinoma tumors and that magnetic fields can strengthen the targeting efficiency (Table 5).

\section{Discussion}

Gene therapy is the insertion of genes into an individual's cells and tissues to treat a disease. For hereditary diseases, the defective mutant allele is replaced with a functional allele. Antisense therapy is not strictly a form of gene therapy, but it is a genetically mediated therapy and is often used together with other methods. Using AS-ODNs to downregulate specific gene products requires oligonucleotides to enter cells and hybridize to the target messenger RNA present in the cytoplasm and/or nucleus. ${ }^{3}$ Nevertheless, the poor ability of oligonucleotides to cross the cell membrane and the degradation of oligonucleotides by DNase I greatly limit their potency. Therefore, it is necessary to identify a safe, effective, and stable gene vector., ${ }^{4,5}$

The development of nanoparticle technology provides a new type of gene vector. Nanoparticles possess several advantages as gene vectors: ${ }^{6}$ ) they are not biologic materials, so they should not induce immune responses; 2) unlike viral carriers, they have
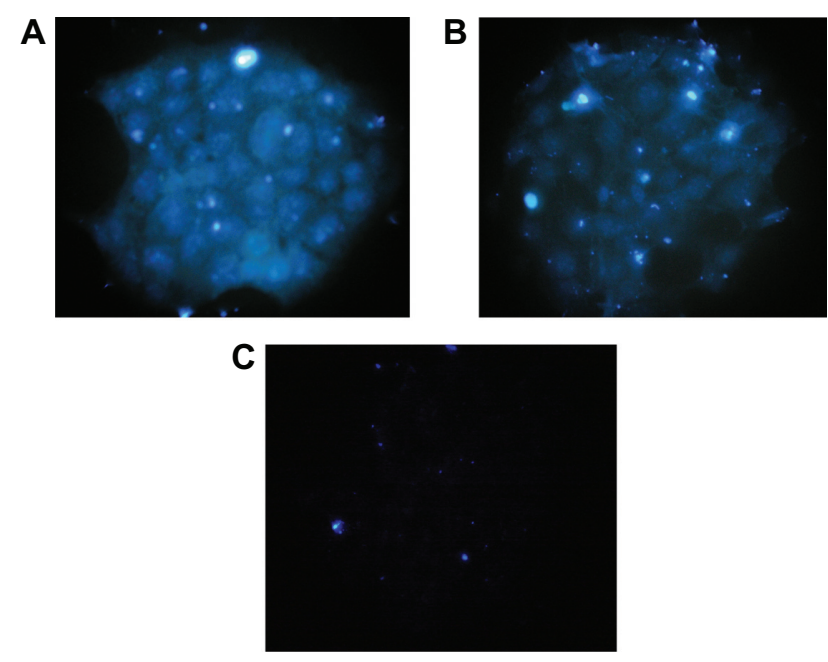

Figure 2 Immunofluorescence staining of $\mathbf{A}$ ) aldehyde $\mathrm{Fe}_{3} \mathrm{O}_{4}$-dextran-anti- $\beta$-HCG nanoparticles, B) anti- $\beta$-HCG antibody, and C) nonaldehyde $\mathrm{Fe}_{3} \mathrm{O}_{4}$-dextran-anti$\beta$-HCG nanoparticle.

Abbreviations: $\mathrm{Fe}_{3} \mathrm{O}_{4}$, magnetic iron oxide; $\mathrm{HCG}$, human chorionic gonadotropin. limited genotoxicity and cytotoxicity; 3) they can mediate the insertion of foreign genes into DNA of host chromosomes, and as a result, foreign genes are stably expressed; 4) they can protect foreign genes from complement and host enzymes; and 5) they can counteract or kill some viruses. With these advantages, nanoparticles have promise as gene vectors.

The feasibility and superiority of $\mathrm{Fe}_{3} \mathrm{O}_{4}$-dextran-anti$\beta$-HCG nanoparticles as gene vector are discussed in the next section.

\section{Preparation and characterization of $\mathrm{Fe}_{3} \mathrm{O}_{4}$-dextran-anti- $\beta$-HCG nanoparticles}

Dextran, $\mathrm{FeCl}_{3}$, and $\mathrm{FeCl}_{2}$ precipitate together under alkaline conditions. As a result, nanometer-sized dextran-coated iron oxide particles may be synthesized. The surface of dextran contains many hydroxyl groups. Once oxidized by $\mathrm{NaIO}_{4}$, these hydroxyl groups can transform to aldehyde

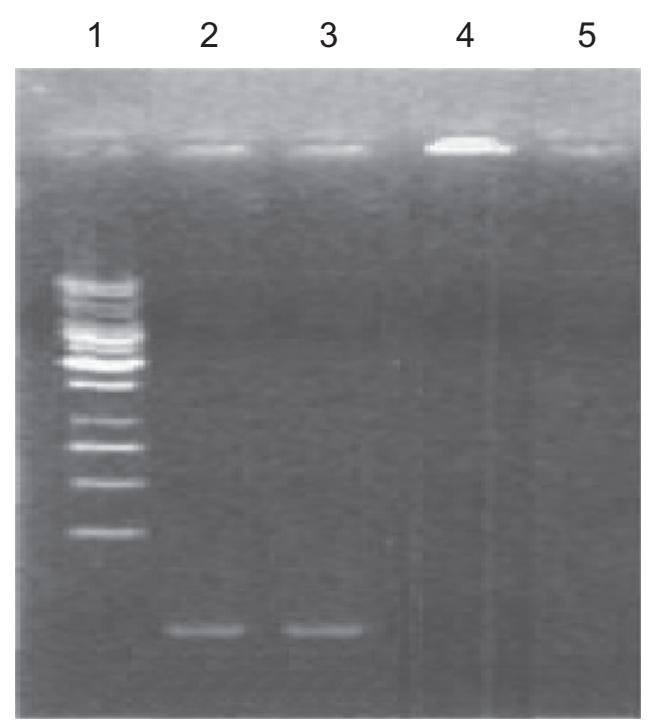

Figure 3 Electrophoresis of simple GAPDH AS-ODN (second track), nonaldehyde $\mathrm{Fe}_{3} \mathrm{O}_{4}$-dextran-anti- $\beta$-HCG-GAPDHAS-ODN (third track), aldehyde $\mathrm{Fe}_{3} \mathrm{O}_{4}$-dextrananti- $\beta$-HCG-GAPDH AS-ODN (fourth track), and $\mathrm{Fe}_{3} \mathrm{O}_{4}$-dextran-anti- $\beta$-HCG nanoparticles (fifth track).

Abbreviations: GAPDH, glyceraldehyde-3-phosphate dehydrogenase; AS-ODN, antisense oligodeoxynucleotides; $\mathrm{Fe}_{3} \mathrm{O}_{4}$, magnetic iron oxide; $\mathrm{HCG}$, human chorionic gonadotropin. 


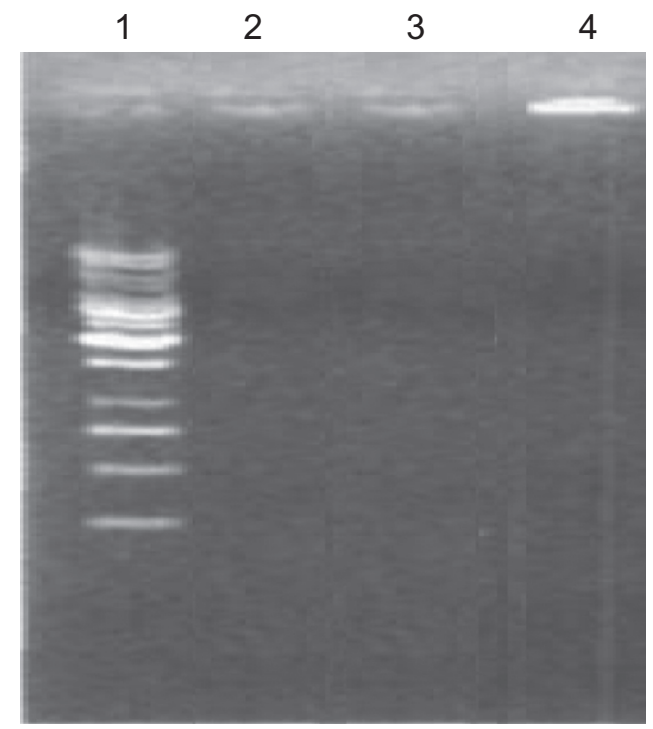

Figure 4 Electrophoresis of simple GAPDH AS-ODN (second track), nonaldehyde $\mathrm{Fe}_{3} \mathrm{O}_{4}$-dextran-anti- $\beta$-HCG-GAPDH AS-ODN (third track), and aldehyde $\mathrm{Fe}_{3} \mathrm{O}_{4}$ dextran-anti- $\beta$-HCG-GAPDH AS-ODN (fourth track) that has been digested by DNase I.

Abbreviations: GAPDH, glyceraldehyde-3-phosphate dehydrogenase; AS-ODN, antisense oligodeoxynucleotides; $\mathrm{Fe}_{3} \mathrm{O}_{4}$, magnetic iron oxide; $\mathrm{HCG}$, human chorionic gonadotropin; DNase I, deoxyribonuclease I.

groups. According to the Schiff reaction, aldehyde dextrancoated iron oxide nanoparticles combine with anti- $\beta-\mathrm{HCG}$ monoclonal antibody and form stable products. BSA is then used to block the surplus hydroxyl groups (Figure 5).

In this study, $\mathrm{Fe}_{3} \mathrm{O}_{4}$-dextran-anti- $\beta$-HCG nanoparticles with an average diameter of $75.5 \mathrm{~nm}$ were synthesized. The results indicate that the magnetic nanoparticles, which have a diameter of $<100 \mathrm{~nm}$, can take therapeutic genes into host cells. Moreover, nanoparticles can be targeted to specific tissues when guided by a magnet. ${ }^{7}$ At the same time, dextran-coated $\mathrm{Fe}_{3} \mathrm{O}_{4}$-dextran-anti- $\beta$-HCG nanoparticles can escape from the reticuloendothelial system and disperse in a fluid medium. These characteristics can help nanoparticles prolong the half-life, and this kind of stability also suggests

Table 3 Fluorescence intensity of nanoparticle mixtures in JEG-3 cells

\begin{tabular}{|c|c|}
\hline Groups & Fluorescence intensity \\
\hline I. Control group & $3.31 \pm 0.37$ \\
\hline $\begin{array}{l}\text { II. } \mathrm{Fe}_{3} \mathrm{O}_{4} \text {-dextran-anti- } \beta \text {-HCG } \\
\text { nanoparticle complexes }\end{array}$ & $9.69 \pm 0.81$ \\
\hline III. GAPDH AS-ODN & $8.41 \pm 0.72$ \\
\hline $\begin{array}{l}\text { IV. } \mathrm{Fe}_{3} \mathrm{O}_{4} \text {-dextran-anti- } \beta \text {-HCG-GAPDH } \\
\text { AS-ODN complexes }\end{array}$ & $26.57 \pm 2.38$ \\
\hline $\begin{array}{l}\text { V. Liposome-GAPDH AS-ODN } \\
\text { complexes }\end{array}$ & $15.36 \pm 1.25$ \\
\hline
\end{tabular}

Abbreviations: GAPDH, glyceraldehyde-3-phosphate dehydrogenase; AS-ODN, antisense oligodeoxynucleotides; $\mathrm{HCG}$, human chorionic gonadotropin; $\mathrm{Fe}_{3} \mathrm{O}_{4}$, magnetic iron oxide.
Table 4 Fluorescence intensity in different cells

\begin{tabular}{ll}
\hline Groups & Fluorescence intensity \\
\hline JEG-3 cells & $26.57 \pm 2.38$ \\
JAR cells & $26.35 \pm 2.27$ \\
RL95-2 cells & $17.24 \pm 1.06$ \\
Hela cells & $16.91 \pm 1.51$ \\
HepG2 cells & $13.26 \pm 1.20$ \\
Lovo cells & $13.77 \pm 1.18$ \\
\hline
\end{tabular}

that $\mathrm{Fe}_{3} \mathrm{O}_{4}$-dextran-anti- $\beta$-HCG nanoparticles can be used as gene vectors.

\section{Biocompatibility of $\mathrm{Fe}_{3} \mathrm{O}_{4}$-dextran- anti- $\beta$-HCG nanoparticles}

Having a safe gene carrier is very important for gene therapy. Studies have confirmed that iron-containing fluids have favorable biocompatibility. Unutilized iron is discharged by skin, gallbladder, and kidney. ${ }^{8,9}$ The biocompatibility of $\mathrm{Fe}_{3} \mathrm{O}_{4}$ particles is improved further with a dextran coating.

In this study, it was found that when the concentration of $\mathrm{Fe}^{3+}$ is $<37.5 \mu \mathrm{g} / \mathrm{mL}$, nanoparticles were not toxic to choriocarcinoma cells.

\section{Immunoreactivity of $\mathrm{Fe}_{3} \mathrm{O}_{4}$-dextran- anti- $\beta$-HCG nanoparticles}

It is important that the process of combining dextran-coated iron oxide nanoparticles with anti- $\beta-H C G$ monoclonal antibody preserves the antibody activity. In this study, it was found that the transfection efficiency of anti- $\beta$-HCG monoclonal antibody activity in aldehyde $\mathrm{Fe}_{3} \mathrm{O}_{4}$-dextran-anti- $\beta$-HCG nanoparticle is higher than $85 \%$, whereas the transfection efficiency of anti- $\beta$-HCG monoclonal antibody activity in nonaldehyde $\mathrm{Fe}_{3} \mathrm{O}_{4}$-dextran-anti- $\beta$-HCG nanoparticle is about $13 \%$. This indicates that nonaldehyde dextran-coated iron oxide nanoparticles do not effectively bind to antibodies, although it is feasible for aldehyde dextran coat iron oxide nanoparticles to preserve antibody activity. To study the interactions between $\mathrm{Fe}_{3} \mathrm{O}_{4}$-dextran-anti- $\beta$-HCG nanoparticles and choriocarcinoma cells, indirect immunofluorescence was used. The results show that $\mathrm{Fe}_{3} \mathrm{O}_{4}$-dextran-anti- $\beta$-HCG nanoparticles can attach to choriocarcinoma cells tightly, indicating that these nanoparticles have excellent discrimination and potency with respect to choriocarcinoma cells.

\section{Capability of $\mathrm{Fe}_{3} \mathrm{O}_{4}$-dextran-anti- $\beta$-HCG nanoparticle as a gene vector}

The surface potential of $\mathrm{Fe}_{3} \mathrm{O}_{4}$-dextran nanoparticle is close to neutral, although the surrounding environment can 
Table 5 Distribution of $\mathrm{Fe}_{3} \mathrm{O}_{4}$-dextran-anti- $\beta$-HCG nanoparticles in nude mice $(\mathrm{mg} / \mathrm{g})$

\begin{tabular}{lllllll}
\hline Group & Heart & Liver & Spleen & Lung & Kidney & Choriocarcinoma tumor \\
\hline I & $0.614 \pm 0.05$ & $1.351 \pm 0.16$ & $0.753 \pm 0.07$ & $0.663 \pm 0.04$ & $0.356 \pm 0.02$ & $5.959 \pm 0.38$ \\
II & $0.598 \pm 0.05$ & $2.994 \pm 0.19$ & $1.805 \pm 0.15$ & $0.586 \pm 0.05$ & $0.394 \pm 0.03$ & $4.112 \pm 0.39$ \\
III & $0.718 \pm 0.09$ & $6.398 \pm 0.65$ & $2.991 \pm 0.24$ & $0.697 \pm 0.07$ & $0.297 \pm 0.02$ & $1.262 \pm 0.11$
\end{tabular}

Abbreviations: HCG, human chorionic gonadotropin; $\mathrm{Fe}_{3} \mathrm{O}_{4}$, magnetic iron oxide.

easily influence its zeta potential. In acidic conditions the zeta potential can become positive, making it possible for $\mathrm{Fe}_{3} \mathrm{O}_{4}$-dextran nanoparticles to bind with the negative surface potential of DNA. In alkaline conditions nanoparticle zeta potential can become negative, making it highly unfavorable for the nanoparticles to bind with DNA. ${ }^{10}$

The $\mathrm{pH}$ of extracellular fluid in human beings is 7.35-7.45, an alkaline environment, so it is unlikely for $\mathrm{Fe}_{3} \mathrm{O}_{4}$-dextran nanoparticles to combine with naked DNA. In this study, DNA was linked with $\mathrm{Fe}_{3} \mathrm{O}_{4}$-dextran-anti$\beta$-HCG nanoparticles using an oxidation-reduction reaction. Electrophoretic analysis indicated that after being oxidized by $\mathrm{NaIO}_{4}, \mathrm{Fe}_{3} \mathrm{O}_{4}$-dextran-anti- $\beta$-HCG nanoparticles obtain the ability to bind with DNA. The principle is similar to that of combining $\mathrm{Fe}_{3} \mathrm{O}_{4}$-dextran nanoparticles with anti- $\beta$-HCG monoclonal antibody. Using flow cytometry, it was also found that $\mathrm{Fe}_{3} \mathrm{O}_{4}$-dextran-anti- $\beta$-HCG nanoparticles can help DNA insert into JEG-3 cells. Moreover, the transfection efficiency of $\mathrm{Fe}_{3} \mathrm{O}_{4}$-dextran-anti- $\beta$-HCG nanoparticles is higher than that for liposomes. This may be due to the small, narrow diameter of $\mathrm{Fe}_{3} \mathrm{O}_{4}$-dextran-anti- $\beta$-HCG nanoparticles, which provides a large specific surface area to bind DNA.

If DNA is digested by nucleases, the transfection efficiency will be reduced. ${ }^{11}$ As a gene vector, nanoparticles have the advantage of protecting DNA from nucleases. ${ }^{12}$ Chavany et $\mathrm{al}^{13}$ reported that poly(alkyl cyanoacrylate) nanoparticles can protect oligonucleotides from nucleases. Cui and Mumper ${ }^{14}$ discovered that free 'naked' plasmid DNA (pDNA) was completely digested by serum nucleases, while the entrapped pDNA remained intact. Moreover, in vitro transfection studies in HepG2 cells showed that pullulan-coated nanoparticles resulted in enhanced luciferase expression, compared with both pDNA alone and uncoated nanoparticles. Nakada et $\mathrm{a}^{15}$ found that nanoparticles could partially protect pdT16 against degradation in the plasma and in the liver $5 \mathrm{~min}$ after administration, whereas free oligonucleotide was totally degraded. In this study, it was also found that $\mathrm{Fe}_{3} \mathrm{O}_{4}$-dextran-anti- $\beta$-HCG nanoparticles protect GAPDH AS-ODN from DNase I. This result is similar to research findings by Xiang et al. ${ }^{16,17}$ Rhaese et a ${ }^{18}$ reported that the reason for the protection is that DNA is surrounded by nanoparticles.

\section{Target of $\mathrm{Fe}_{3} \mathrm{O}_{4}$-dextran-anti- $\beta$-HCG nanoparticle}

Developing targeted gene vectors is a very active area of research in the field of genes therapy. In the absence of tissue-specific targeting, therapeutic genes will spread

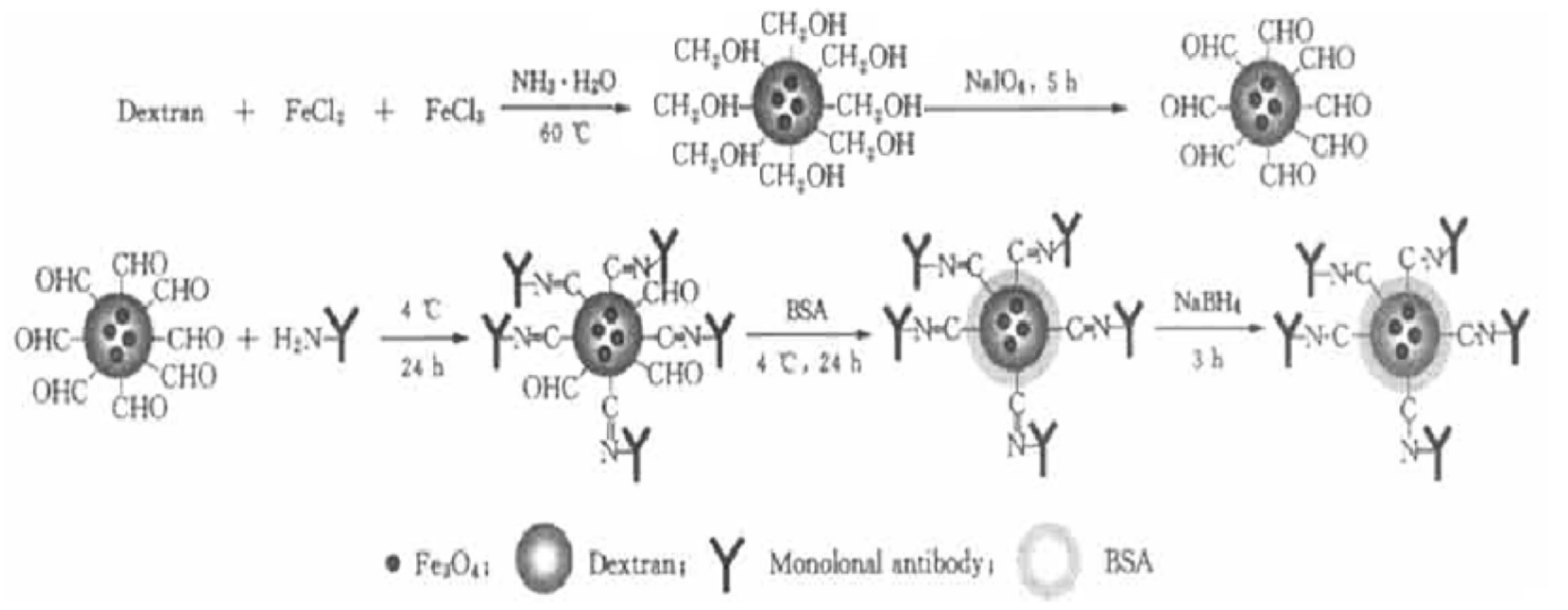

Figure 5 Theory of how $\mathrm{Fe}_{3} \mathrm{O}_{4}$-dextran-anti- $\beta$-HCG nanoparticles are prepared.

Abbreviations: $\mathrm{Fe}_{3} \mathrm{O}_{4}$, magnetic iron oxide; $\mathrm{HCG}$, human chorionic gonadotropin; $\mathrm{BSA}$, bovine serum albumin. 
to all organs through blood flow. This will not only reduce the drug concentrations in diseased organs, but also cause side effects. Researchers are, therefore, doing their best to increase drug concentrations in diseased organs, while decreasing the drug concentrations in other organs. As a gene vector, nanoparticles are of interest because they can impact distribution of DNA in the body due to targeting capabilities. Nanoparticle targeting can be divided into passive targeting and active targeting. ${ }^{6}$

In passive targeting, nanoparticles are taken into the reticuloendothelial system, such as the liver, spleen, and lymph, which is beneficial to diseases of the reticuloendothelial system. However, when being used to treat tumors, nanoparticles are expected to assemble in the tumor itself, so the need to obtain active targeting becomes even more important.

Active targeting is subdivided into physical, chemical, and biological targeting. Physical and chemical targeting are realized according to the $\mathrm{pH}$, temperature, and magnetism of the nanoparticle, whereas biological targeting is realized according to the antigen and acceptor on the surface of nanoparticle.

To target choriocarcinomas, it is important to reduce the amount of nanoparticle that is absorbed by the reticuloendothelial system. $\mathrm{Fe}_{3} \mathrm{O}_{4}$-dextran-anti- $\beta$-HCG nanoparticles that possess magnetic- and immune-targeting capabilities were prepared. To demonstrate nanoparticle targeting, the absorption of $\mathrm{Fe}_{3} \mathrm{O}_{4}$-dextran-anti- $\beta$-HCG-GAPDH AS-ODN in different cells was tested. The transfection efficiency of $\mathrm{Fe}_{3} \mathrm{O}_{4}$-dextran-anti- $\beta$-HCG nanoparticles in choriocarcinoma JEG-3 and JAR cells was found to be much higher than that in RL95-2, Hela, HepG2, and Lovo cells. This indicates that anti- $\beta$-HCG monoclonal antibody in $\mathrm{Fe}_{3} \mathrm{O}_{4}$-dextran-anti$\beta$-HCG nanoparticles combined specifically with $\beta-\mathrm{HCG}$ antigen in choriocarcinoma cells. In other words, these nanoparticles have characteristics of biological targeting. However, it was also found that when using magnetic and immune targeting together, $\mathrm{Fe}_{3} \mathrm{O}_{4}$-dextran-anti- $\beta$-HCG nanoparticles are absorbed into the target reticuloendothelial system and assemble in the choriocarcinoma tumor. Furthermore, the combined effect of magnetic and immune targeting is stronger than that of magnetic targeting or immune targeting alone.

\section{Conclusion}

In summary, $\mathrm{Fe}_{3} \mathrm{O}_{4}$-dextran-anti- $\beta$-HCG nanoparticles represent an appropriate vector for gene therapy and demonstrate strong resistance to degradation. They combine high transfection efficiency with good biocompatibility and low cytotoxicity. Because they can be targeted using magnetic and antibody recognition mechanisms, they offer the possibility for additional targeting strategies beyond those currently in use.

\section{Acknowledgment}

We greatly appreciate the National Hepatobiliary and Enteric Surgery Research Center for their help with the manuscript. This study was conducted at Xiangya Hospital, Central South University, Changsha, Hunan, China.

\section{Disclosure}

The authors report no conflicts of interest in this work.

\section{References}

1. Pattinson SD. Regulating germ-line gene therapy to avoid sliding down the slippery slope. Med Law Int. 2000;4(3-4):213-222.

2. Xia H, Wei G, Jun L, et al. Preparation of nano-scaled magnetic biological probes of $\mathrm{Fe}_{3} \mathrm{O}_{4}$ /dextran/antibody and chromatographic assay. Gaodeng Xиехiao Huaxue Xиebao. 2004;25(3):445-447.

3. Zelphati O, Szoka FC Jr. Intracellular distribution and mechanism of delivery of oligonucleotides mediated by cationic lipids. Pharm Res. 1996;13(9):1367-1372.

4. Legrand V, Leissner P, Winter A, Mehtali M, Lusky M. Transductional targeting with recombinant adenovirus vectors. Curr Gene Ther. 2002; 2(3):323-339.

5. Wolf JK, Jenkins AD. Gene therapy for ovarian cancer (review). Int $J$ Oncol. 2002;21(3):461-468.

6. Zhang YD. Nanobiotechnology. Beijing, China: Scientific Publishing Company; 2005:1.

7. Lambert G, Fattal E, Couvreur P. Nanoparticulate systems for the delivery of antisense oligonucleotides. Adv Drug Deliv Rev. 2001; 47(1):99-112.

8. Wagner S, Schnorr J, Pilgrimm H, Hamm B, Taupitz M. Monomercoated very small superparamagnetic iron oxide particles as contrast medium for magnetic resonance imaging: preclinical in vivo characterization. Invest Radiol. 2002;37(4):167-177.

9. Lawaczeck R, Bauer H, Frenzel T, et al. Magnetic iron oxide particles coated with carboxydextran for parenteral administration and liver contrasting. Pre-clinical profile of SH U555A. Acta Radiol. 1997; 38(4 Pt 1):584-597.

10. Kneuer C, Sameti M, Haltner EG, et al. Silica nanoparticles modified with aminosilanes as carriers for plasmid DNA. Int J Pharm. 2000; 196(2):257-261.

11. Ogris M, Wagner E. Targeting tumors with non-viral gene delivery systems. Drug Discov Today. 2002;7(8):479-485.

12. Lambert G, Fattal E, Pinto-Alphandary H, Gulik A, Couvreur P. Polyisobutylcyanoacrylate nanocapsules containing an aqueous core as a novel colloidal carrier for the delivery of oligonucleotides. Pharm Res. 2000;17(6):707-714.

13. Chavany C, Le Doan T, Couvreur P, Puisieux F, Hélène C. Polyalkylcyanoacrylate nanoparticles as polymeric carriers for antisense oligonucleotides. Pharm Res. 1992;9(4):441-449.

14. Cui Z, Mumper RJ. Plasmid DNA-entrapped nanoparticles engineered from microemulsion precursors: in vitro and in vivo evaluation. Bioconjug Chem. 2002;13(6):1319-1327.

15. Nakada Y, Fattal E, Foulquier M, Couvreur P. Pharmacokinetics and biodistribution of oligonucleotide adsorbed onto poly(isobutylcyanoacrylate) nanoparticles after intravenous administration in mice. Pharm Res. 1996;13(1):38-43. 
16. Xiang JJ, Zhu SG, Lv HB, et al. Use of magnetic iron oxide nanoparticles as gene carrier. Chin J Cancer. 2001;20(10):1009-1014.

17. Xiang JJ, Tang JQ, Zhu SG, et al. IONP-PLL: a novel nonviral vector for efficient gene delivery. J Gene Med. 2003;5(9): 803-817.
18. Rhaese S, von Briesen H, Rübsamen-Waigmann H, Kreuter J, Langer K. Human serum albumin-polyethylenimine nanoparticles for gene delivery. J Control Release. 2003;92(1-2):199-208.

\section{Publish your work in this journal}

The International Journal of Nanomedicine is an international, peerreviewed journal focusing on the application of nanotechnology in diagnostics, therapeutics, and drug delivery systems throughout the biomedical field. This journal is indexed on PubMed Central, MedLine, CAS, SciSearch $\AA$, Current Contents ${ }^{\circledR} /$ Clinical Medicine,
Journal Citation Reports/Science Edition, EMBase, Scopus and the Elsevier Bibliographic databases. The manuscript management system is completely online and includes a very quick and fair peer-review system, which is all easy to use. Visit http://www.dovepress.com/ testimonials.php to read real quotes from published authors.

Submit your manuscript here: http://www.dovepress.com/international-journal-of-nanomedicine-journal 